\title{
First Record of Ades masidai(Nakane, 1963) from Korea (Coleoptera: Tenebrionidae: Leiochrinini)
}

\author{
Boo Hee Jung* \\ Korean Entomological Institute, Korea University, Seoul 136-701, Korea \\ 한국산 미기록종 여수둥글거저리의 보고
[딱정벌레목: 거저리과: 둥를거저리족] \\ 정부희* \\ 고려대학교 한국곤충연구소
}

\begin{abstract}
The tribe Leiochrinini of Diaperinae (Tenebrionidae) is presented for the first time from Korea. One unrecorded species, Ades masidai Nakane, 1963 are reported. Morphological photographs of adult, redescription and illustrations of diagnostic characteristics are provided.
\end{abstract}

Key words: Ades masidai Nakane, Leiochrinini, Diaperinae, Tenebrionidae, Taxonomy, New record.

초 록: 한국산 거저리과 르위스거저리아과에 속한 미기록종 Ades masidai Nakane (딱정벌레목: 거저리과) 보고하고자 한다. 이 종에 대한, 재기 재문, 진단형질 그림과 성충사진을 표시하였다.

검색어: 거저리과, 둥글거저리족(Leiochrinini), 여수둥글거저리(Ades masidai Nakane), 미기록족, 미기록종, 분류.

Tribe Leiochrinini of Diaperinae in family Tenebrionidae is mostly distributed in the Asian Palaearctic and Oriental Region. This tribe consists of 91 species of 9 genera in the Palaeartic region (Löbl et al., 2008). Members of Leiochrinini are recognized as follows: body nearly hemispherical, strongly convex, strongly glabrous, head conceal under pronotum, antennae rather robust and gradually from antennomeres 5 to 11 , penultimate tarsomeres dilated, lobed beneath, distinctly broader than apical tarsomere (Lewis, 1894).

Among them, genus Ades Guérin-Méneville is mostly distributed in the the Asian Palaeartic and Oriental Region. This genus consists of 19 species in the Palaeartic region (Löbl et al, 2008).

*Comesponding author: starrylight12@hanmail.net

Received September 22 2012; Revised February 42013

Accepted February 202013
In this paper, the genus Ades belonging to Leiochrinini is reported, as representative species by Ades masidai (Nakane, 1963) for the first time from Korea. Redescription, photos of adult, and illustrations of diagnostic characteristic are provided.

Materials for this study were collected in damp decaying plants and are deposited in JUNG's Insect Collection (Seoul, Korea).

\section{Systematic accounts}

Tribe Leiochrinini Lewis, 1894 둥글거저리족(신칭)

Leiochrinini Lewis, 1894: 300.

Type genus: Leiochrinus Westwood, 1883. 

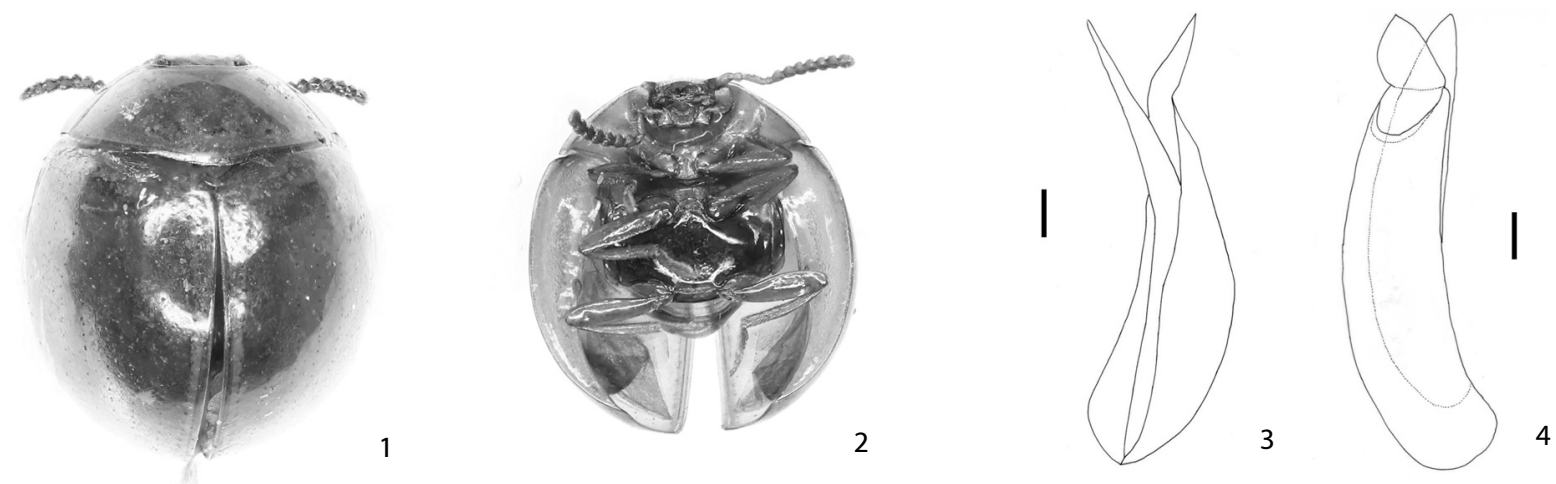

Figs. 1-2. Adults of Ades masidai (Nakane). 1. dorsal view; 2. ventral view.

Figs. 3-4. Genitalia of Ades masidai (Nakane). (Each scale bar $=0.1 \mathrm{~mm}$ ). 3. latero-ventral view; 4. dorso-lateral view.

Genus Ades Guérin-Méneville, 1857 둥글거저리속(신칭) Ades Guérin-Méneville, 1857: 277.

Leiochrodes Westwood, 1883: 69.

Leichrota Westwood, 1883: 70.

Type species: Ades hemisphericus Guérin-Méneville, 1857

\section{Ades masidai (Nakane, 1963) 여수둥글거저리(신칭)}

(Figs. 1, 2, 3, 4)

Leiochrodes masidai Nakane, 1963: 26.

Redescription. Body length $3.0 \mathrm{~mm}$; body hemispherical, strongly convex and glossy; mostly reddish brown in color, except blackish brown from antennomere 5 to 11 and ventral part (often). Head entirely concealed under pronotum; weakly convex, without punctures; frons smooth and weakly convex; eyes slightly emarginate; antenna relatively short and robust, not reaching to pronotum; submoniliform, widened from fifth antennomere to apical one; first antennomere ovate, second antennomere short, third antennomere elongate, about twice longer than second antennomere; fourth antennomere very small; fifth and sixth antennomeres serrated inner part, seventh to 11 th antennomere gradually widened inner and outer sides; apical antennomere nearly circular; clypeus with sparse and stiff setae; apical maxillary palpomere thickly cylindrical; apical labial palpomere thinly cylindrical, tapered apically. Pronotum fan-shaped, glabrous, strongly shining, invisible punctures (x40 magnification); all margins rimmed; anterior margin strongly arched; lateral sides strongly narrowed apically; basal margin strongly arched; scutellum triangular. Elytra strongly convex, glabrous, and invisible hairs (x40 magnification); strongly narrowed apically, forming an almost complete circular outline; strial punctures very sparse, small and shallow, forming rows of punctures. Fore tibiae of leg gradually enlarged with strong setae outside; all tarsomeres lobed ventrally with strong and stiff setae.

Type Locality: Miho (sea beach), Naka-gun, Shimane, Honshu (holotype: 3 exs 1954, K. Masida leg.)

Specimens examined: 5 exs. Yeosu-si, Jeollanamdo, Korea, 20 III 2011, S.-S. Lee under the dried pumpkin stems.

Biological notes. This species occurs under damp decaying leaves in early spring (Nakane, 1963).

Distribution. Korea (New to Korea), Japan

\section{Acknowledgement}

Thanks are due to Mr. Sangsoo Lee, who provided materials for this study. This study was carried out through "The Survey of Korean Indigenous Species" supported by National Institute of Biological Resources (NIBR) of Ministry of Environment of Korea.

\section{Literature Cited}

Guérin-Méneville, F.E., 1857. Matériaux pour une monographie des coléoptères du group des eumorphides et plus spécialement du genre Eumorphus. pp. 237-280. In: Thompson J. (Eds.), Archives Entomologiques ou recueil contenant des illustrations d'insectes nouveaux ou rares. Tome premier: XXI pls., Bureau du Trésorier de la Société Entomologique de France, Paris, pp. 512. 
Löbl, I., Merkl, K., Ando, K., Bouchard, P., Lillig, M., Masumoto, Schawaller, W., 2008. Family Tenebrionide. Latreille, 1802. pp. 105-352 In: Löbl, I. \& A. Semetana (Eds.), Catalogue of Palaearctic Coleoptera. Vol. 5. Tenebrionoidea. Apollo Books, Stenstrup, Denmark.
Lewis, G., 1894. On the Tenebrionidae of Japan. Ann. Mag. Nat. Hist. 13: 377-484.

Nakane, T. 1963. New or little-known Coleopteara from Japan and its adjacent region. XIX. Frag. Coleopt. 6: 26-30.

Westwood, J.O., 1883. Descriptions of some new exotic Coleoptera. Tijd. Entomol. 26: 61-78. 